\title{
PENGEMBANGAN UMPAN RAMAH LINGKUNGAN TERHADAP RAYAP TANAH (Coptotermes curvignathus Holmgren)
}

\author{
(Development of environmentally friendly bait against subterranean termites Coptotermes \\ curvignathus Holmgren)
}

\author{
Dewi Fatmawati, Muflihati \\ Fakultas Kehutanan Universitas Tanjungpura, Jl. Daya Nasional Pontianak, 78124 \\ Email: dewyfatmawatii@gmail.com
}

\begin{abstract}
Bait technology is the most effective, safe, and environmentally friendly way to termite control. This method was done by utilize attractants which have properties or aromas and able to invite termites to eat the bait. M. leucadendra leaves potentially used as an attractant. The matrix of bait material used as attractant to termites should contain high cellulose compound.. HVS paper and cardboard are materials with high cellulose compound, so they can used as bait. The aim of this study was to examine the efficacy of bait from M. leucadendra leaf mixture with waste paper to subterranean termites (Coptotermes curvignathus Holmgren) and to determine the optimal composition of the mixture of waste paper and M. leucadendra leaves which can be used as bait against termites. Tests are carried out with 2 methods, namely no choice test and multiple choice test. No-choice test was done by forced feeding, which was only one test sample in the test cup, with 55 termites (50 workers caste and 5 soldiers caste). Multiple choice test was done by giving food choices, which are all test samples for each composition in the test cup, with 165 termites (150 workers caste and 15 soldiers caste). The parameters observed were the weight loss of bait and mortality of termites. The results shows that the bait of the mixture of $M$. leucadendra leaves and paper waste in the no choice test and multiple choice test was effective used as bait to termites. Mixture of M. leucadendra: cardboard (60\%: 40\%) is the best composition bait for Subterranean C. curvignathus.
\end{abstract}

Keyword: Baiting method, bioattractant, Coptotermes curvignathus, M. leucadendra leaves, wastepaper

\section{PENDAHULUAN}

Rayap merupakan salah satu kelompok serangga (insect) sosial yang hidupnya membentuk suatu komunitas biasanya dikenal dengan istilah koloni (Nandika et al, 2003). Menurut Subekti (2012), serangan rayap tanah pada kayu konstruksi bangunan dan bahan lignoselulosa lainnya telah dilaporkan hampir di seluruh Indonesia, bahkan pada bangunan terus meningkat dari tahun ke tahun. Oleh karena itu, metode dalam pengendalian rayap terus dikembangkan. Tarumingkeng (2001), menyatakan bahwa bahan pengawet yang dimasukkan ke dalam kayu umumnya merupakan bahan beracun (toxic material) agar jasad hidup perusak kayu tidak menyerang.

Pengendalian rayap masih banyak menggunakan anti rayap (termitisida) yang di aplikasikan baik melalui teknik perlakuan tanah (soil treatment), pengawetan kayu (wood preservation) maupun dengan cara impregnasi termitisida kedalam target, tetapi termitisida dapat menimbulkan masalah lingkungan dan berpotensi meracuni manusia. Teknologi umpan merupakan 
cara yang paling efektif, aman, dan ramah lingkungan karena racun dapat dimasukkan ke dalam umpan untuk menghilangkan koloni rayap (Huang et al. 2006). Metode pengumpanan dapat dilakukan dengan memanfaatkan atraktan yang merupakan salah satu bahan yang memiliki sifat atau aroma yang mampu mengundang rayap untuk masuk memakan umpan tersebut. Atraktan alami atau bioatraktan dapat diperoleh dari berbagai jenis tanaman yang memiliki aroma khas karena memiliki kandungan senyawa eugenol dan turunannya metil eugenol yang telah dikenal sebagai atraktan alami (Noviansari et al. 2013). Daun kayu putih berpotensi digunakan sebagai atraktan untuk pengendalian rayap dengan sistem umpan, karena mengandung sineol dan eugenol (Indrayani et al. 2016). Matrik atau bahan pembuatan umpan yang dapat digunakan untuk menarik rayap ialah dengan menggunakan bahan yang mengandung selulosa tinggi, salah satu bahan itu adalah kertas. Jenis - jenis kertas yang dapat digunakan sebagai umpan ialah limbah kertas HVS dan limbah kardus.

Penelitian sebelumnya, Septiana dan Husni (2017) memberikan informasi bahwa daun kayu putih tanpa proses ekstraksi dan limbah kertas HVS pada komposisi campuran 60\% : 40\% yang dicetak dengan kerapatan $0,5 \mathrm{gram} / \mathrm{cm}^{2}$ efektif sebagai bioatraktan pada rayap tanah (C. curvignathus) dengan kehilangan berat $10,79 \%$ dan mortalitas rayap 38,67\%. Penelitian Permana dan Husni (2017), membuktikan bahwa komposisi bahan kayu pinus terdegradasi jamur : limbah kertas HVS : limbah kardus dengan perbandingan 1:1:1 yang dicetak dengan kerapatan $0,7 \mathrm{gram} / \mathrm{cm}^{2}$ dan konsentrasi ekstrak $0,01 \%$ daun kayu putih sudah efektif sebagai bioatraktan bagi rayap tanah C. curvignathus menyebabkan kehilangan berat 10,7685 (no-choice test), 9,3863\% (multiple choice test) dan mortalitas rayap $51,3333 \%$.

Berdasarkan informasi dari penelitian yang telah dilakukan, maka perlu dilakukan penyempurnaan penelitian dengan menggunakan limbah kertas HVS dan limbah kardus dalam pengujian campuran bioatraktan daun kayu putih tanpa proses ekstraksi dengan target kerapatan 0,8 gram $/ \mathrm{cm}^{2}$. Target kerapatan dibuat untuk menambah jumlah bahan yang digunakan sebagai umpan. Permasalahannya adalah, belum diketahui komposisi optimal campuran limbah kardus dan kertas HVS dengan $60 \%$ daun kayu putih yang dapat berfungsi sebagai umpan terhadap rayap tanah (C. curvignathus).

Penelitian ini bertujuan untuk menguji efikasi (keampuhan) umpan dari campuran daun kayu putih dengan limbah kertas HVS dan kardus terhadap rayap tanah $(C$. curvignathus) di laboratorium dan menentukan komposisi terbaik campuran limbah kertas HVS, kertas kardus, dan daun kayu putih yang dapat berfungsi sebagai umpan terhadap rayap tanah.

\section{METODE PENELITIAN}

Penelitian dilaksanakan di Laboratorium Wood Work Shop Fakultas Kehutanan Universitas Tanjungpura sebagai tempat persiapan bahan dan Laboratorium Teknologi Kayu Fakultas Kehutanan Universitas Tanjungpura sebagai tempat uji efikasi, dimulai dari November hingga Desember 2018. Alat 
yang digunakan pada penelitian ini adalah ember, kain hitam, cawan plastik, kotak plastik, aluminium foil, desikator, kapas, bulu ayam, kertas label, kasa plastik, mesh screen 30/50, hammer mill, cetakan seng, gunting, dan hygrothermometer. Bahan yang digunakan pada penelitian ini adalah daun kayu putih yang diperoleh di Jl. A yani Pontianak, rayap tanah yang diperoleh dari desa Ambawang, aquades, limbah kertas HVS dan kardus, pasir steril, dan alkohol 70\%.

\section{Pengadaan dan Pemeliharaan Rayap}

Koloni rayap $C$. curvignathus diperoleh dari sisa pohon yang sudah mati dan tumbang. Kayu yang terserang rayap di potong menjadi beberapa bagian, kemudian diletakkan dalam ember. Ember yang berisi rayap dijaga kelembabannya dengan memberikan wadah dibawahnya yang telah berisi air dan ditutup dengan kain hitam. Koloni rayap selanjutnya dipelihara di dalam ruangan selama \pm satu bulan sebelum digunakan sebagai organisme uji (Permana dan Husni, 2017)

\section{Persiapan Daun Kayu Putih}

Persiapan daun kayu putih dilakukan mengacu pada penelitian Septiana dan Husni (2017) yang telah dimodifikasi. Daun kayu putih diambil dari pohon dalam kondisi segar, daun yang diambil adalah daun tua. Daun dipisahkan dari rantingranting kecil yang masih tersisa, dan dikering udarakan selama 8 hari. Daun yang telah dalam kondisi kering udara tersebut disimpan dalam plastik packing yang kedap udara. Untuk keperluan pembuatan sampel, daun kayu putih tersebut dihaluskan menggunakan hammer mill dengan ukuran 20 mesh

\section{Persiapan Limbah Kertas HVS dan Kardus}

Kertas HVS yang digunakan dalam penelitian adalah limbah kertas HVS yang sudah tidak digunakan lagi, sedangkan kardus yang digunakan adalah bagian tengah dari kardus yang bergelombang. Kertas HVS dan kardus di gunting atau sobek dengan ukuran kecil, kemudian dijemur di bawah sinar matahari selama 24 jam. Kertas yang telah dijemur disimpan dalam plastik kedap udara. Untuk keperluan pembuatan sampel uji, kertas di hancurkan menggunakan hammer mill dengan ukuran 20 mesh

Pembuatan Contoh Uji

Kertas HVS dan kardus ditimbang sesuai perlakuan (Tabel 1), selanjutnya direndam dalam aquades selama \pm 10 menit, dengan tujuan untuk memudahkan pencampuran antara kertas dengan daun kayu putih. Setelah 10 menit kertas diperas menggunakan kain furing dan dicampur dengan daun kayu putih yang telah dihaluskan. Perbandingan keperluan bahan untuk setiap perlakuan dapat di lihat pada Tabel 1.

\section{Tabel 1. Perhitungan Keperluan Bahan Pembuatan Sampel (Calculation of requirements for making samples test)}

\begin{tabular}{cccccc}
\hline Perlakuan & $\begin{array}{c}\text { Perbandingan Bahan } \\
\text { (DKP : HVS: K) }\end{array}$ & $\begin{array}{c}\text { Serbuk Daun Kayu } \\
\text { Putih }(\mathrm{gr})\end{array}$ & $\begin{array}{c}\text { Serbuk } \\
\text { HVS (gr) }\end{array}$ & $\begin{array}{c}\text { Serbuk Kardus } \\
\text { (gr) }\end{array}$ & $\begin{array}{c}\text { Berat } \\
\text { total (gr) }\end{array}$ \\
\hline A1 & $60 \%: 20 \%: 20 \%$ & 1,92 & 0,64 & 0,64 & 3,2 \\
A2 & $60 \%: 40 \%: 0 \%$ & 1,92 & 1,28 & - & 3,2 \\
A3 & $60 \%: 0 \%: 40 \%$ & 1,92 & - & 1,28 & 3,2 \\
\hline
\end{tabular}

Keterangan: DKP = Daun kayu putih; HVS = HVS; K= Kardus 
Contoh uji dicetak menggunakan cetakan seng berukuran $2 \mathrm{~cm}$ x $2 \mathrm{~cm} \times 1$ $\mathrm{cm}$. Tahap selanjutnya, sampel dikondisikan kering udara selama 24 jam, kemudian dikeluarkan dari cetakan dan ditimbang untuk mengetahui berat sebelum pengovenan. Contoh uji di oven dengan suhu $40 \pm 2^{0} \mathrm{C}$ selama 48 jam (Septiana dan Husni, 2017) , dan ditimbang untuk mengetahui berat setelah pengovenan (berat awal sebelum pengujian).

Pengujian Umpan Terhadap Rayap

1. Pengujian Tanpa Pilihan (No-Choice Test)

Pengujian dilakukan dengan menggunakan metode Ohmura et al. (2000) yang telah dimodifikasi. Wadah pengujian dengan menggunakan cawan plastik berukuran diameter $6 \mathrm{~cm}$ dan tinggi $6 \mathrm{~cm}$. Masing-masing cawan diisi dengan pasir steril setinggi $\pm 1 \mathrm{~cm}$ dan dibasahi dengan aquades sebanyak $3 \mathrm{ml}$ untuk menjaga kelembabannya. Di atas pasir diberi kasa plastik berukuran diameter $4 \mathrm{~cm}$ untuk mencegah sampel kontak langsung dengan pasir. Memasukkan satu contoh uji untuk setiap perlakuan ke dalam setiap cawan plastic. Selanjutnya ke dalam cawan plastik dimasukkan rayap C. curvignathus sebanyak 50 ekor rayap pekerja dan 5 ekor rayap prajurit. Cawan tersebut selanjutnya diletakkan pada kotak plastik yang pada bagian bawahnya diberi kapas basah, dan disimpan dalam ruang gelap selama 21 hari.

2. Pengujian Dengan Pilihan (Multiple Choice Test)

Pengujian dilakukan mengacu pada penelitian Permana dan Husni (2017). Pengujian multiple choice test menggunakan cawan plastik berukuran diameter $12 \mathrm{~cm}$ dan tinggi $6 \mathrm{~cm}$. Setiap cawan di isi pasir setinggi $\pm 1 \mathrm{~cm}$ dan dibasahi air sebanyak $20 \mathrm{ml}$ untuk menjaga kelembabannya. Di atas pasir diberi kasa plastik berukuran diameter $10 \mathrm{~cm}$ untuk mencegah sampel kontak langsung dengan pasir. Sebanyak satu contoh uji dari seluruh perlakuan (A1, A2, dan A3) dimasukkan ke dalam cawan plastik. Selanjutnya ke dalam cawan dimasukkan rayap tanah sebanyak 165 ekor dengan perbandingan 150 ekor rayap kasta pekerja dan 15 ekor rayap kasta prajurit. Cawan-cawan tersebut disimpan dalam ruang gelap selama 21 hari. Pengujian dilakukan sebanyak 3 ulangan. contoh uji yang dimasukkan ke dalam setiap cawan hanya satu buah untuk setiap perlakuan. Kemudian ke dalam cawan plastik dimasukkan rayap C. curvignathus sebanyak 50 ekor rayap pekerja dan 5 ekor rayap prajurit. Cawan tersebut selanjutnya diletakkan pada kotak plastik yang pada bagian bawahnya diberi kapas basah, dan disimpan dalam ruang gelap selama 21 hari.

\section{Perhitungan Mortalitas Rayap}

Penentuan nilai mortalitas menggunakan rumus yang dikemukakan oleh Zulyusri et al. (2013), yakni :

Mortalitas rayap (\%)

$=\frac{\text { Jumlah rayap yang mati pada akhir pengamatan }}{\text { Jumlah rayap awal pengumpanan }} \times 100 \%$

\section{Kehilangan Berat Umpan}

Kehilangan berat umpan dihitung dengan menggunakan rumus sebagai berikut :

Kehilangan Berat (\%)

$=\frac{\text { Berat awal-berat akhir }}{\text { Berat akhir }} \times 100 \%$

Rancangan Penelitian 
Penelitian ini menggunakan model Rancangan Acak Lengkap (RAL), yang terdiri dari 1 faktor yaitu komposisi bahan antara daun kayu putih, kertas HVS dan kardus, dengan 3 taraf yaitu : A1 (Daun kayu putih $60 \%+$ HVS $20 \%+$ Kardus 20\%); A2 (Daun kayu putih 60\% + HVS 40\%); dan A3 (Daun kayu putih 60\% + Kardus 40\%). Analisis data menggunakan Analisis Sidik Ragam (Anova) dan uji lanjut menggunakan uji Beda Nyata Jujur (BNJ).

\section{HASIL DAN PEMBAHASAN}

Pengujian efikasi ini menggunakan dua metode pengujian, yaitu pengujian tanpa pilihan (no-choice test) dan pengujian dengan pilihan (multiple choice test). Efikasi umpan dari campuran daun kayu putih dengan campuran limbah kertas dapat dilihat dari persentase kehilangan berat dan mortalitas (kematian) rayap tanah selama masa pengujian.

\section{Kehilangan Berat (Weight Loss) Contoh Uji}

Persentase kehilangan berat contoh uji dengan metode pengujian no-choice test yang diperoleh pada pengujian berkisar antara 2,99\% hingga mencapai 5,478\%. Untuk lebih jelasnya, kehilangan berat contoh uji pada no-choice test disajikan pada Gambar 1.

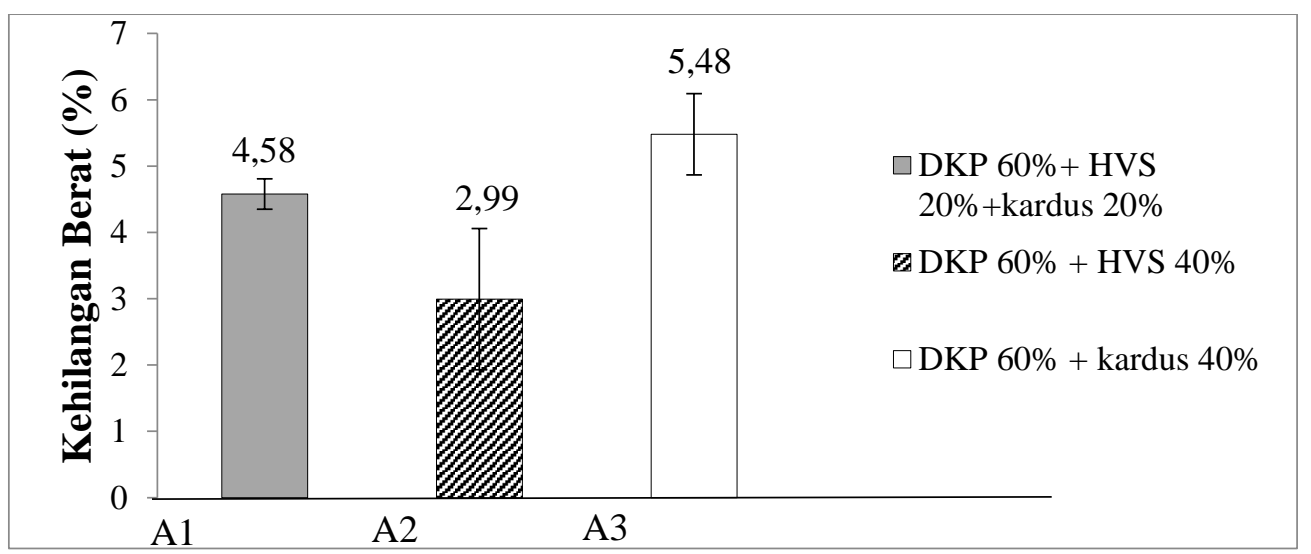

Gambar 1. Kehilangan Berat Pada No-Choice Test (Weight Loss of No-Choice Test)

Gambar 1 menunjukkan bahwa kehilangan berat contoh uji pada pengujian no-choice test berdasarkan komposisi daun kayu putih:HVS:Kardus (60\%:20\%:20\%) dan daun kayu putih:Kardus (60\%:40\%) menunjukkan hasil yang sama. Komposisi umpan tanpa adanya penambahan kertas HVS $20 \%$ menunjukkan adanya peningkatan nilai kehilangan berat contoh uji pada pengujian no-choice. Berdasarkan hasil yang diperoleh, maka komposisi daun kayu putih : kardus (60\%:40\%) merupakan komposisi terbaik sebagai umpan untuk rayap tanah $C$. curvignathus pada pengujian no-choice test.

Persentase kehilangan berat contoh uji dengan metode pengujian multiple choice test yang diperoleh pada pengujian berkisar antara 2,89\% hingga mencapai $5,25 \%$. Untuk lebih jelasnya, kehilangan berat contoh uji pada multiple choice test disajikan pada Gambar 2. 


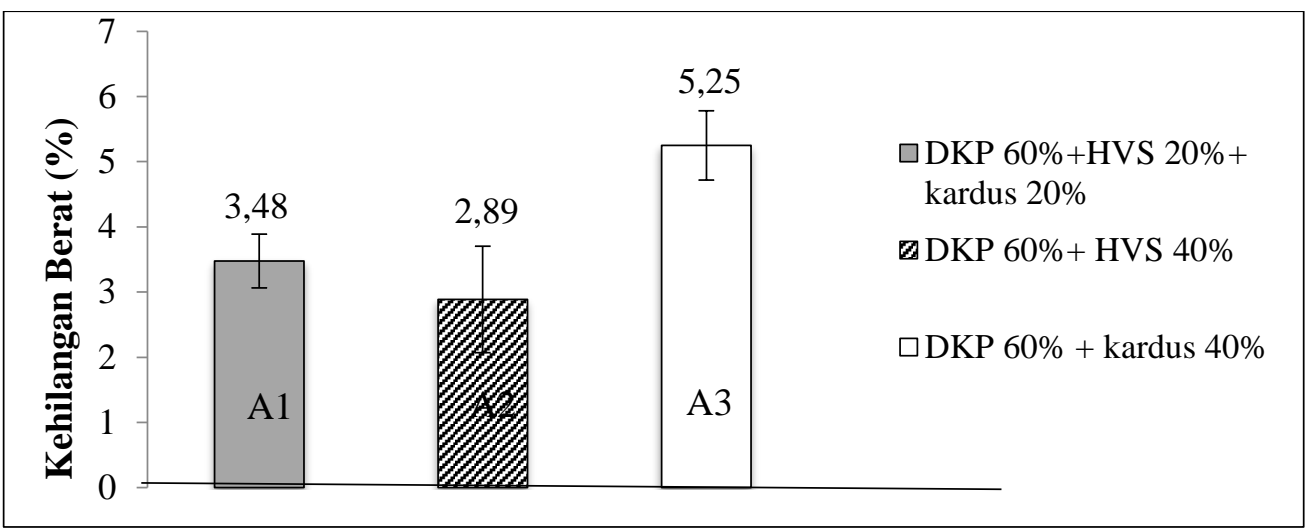

Gambar 2. Kehilangan Berat Pada Multiple Choice Test (Weight Loss of Multiple Choice Test)

Gambar 2 menunjukkan bahwa kehilangan berat contoh uji pada pengujian multiple choice test berdasarkan komposisi daun kayu putih:HVS:Kardus (60\%:20\%:20\%) dan daun kayu putih:HVS (60\%:40\%) memberikan hasil yang sama. Komposisi umpan tanpa adanya penambahan kertas HVS menghasilkan nilai kehilangan berat yang berbeda dibandingkan dengan komposisi lainnya pada pengujian multiple choice. Berdasarkan hasil yang diperoleh, maka komposisi daun kayu putih: kardus (60\%:40\%) merupakan komposisi terbaik sebagai umpan untuk rayap tanah $C$. curvignathus pada pengujian multiple choice test.

Secara umum dapat dikatakan bahwa semua umpan yang diujikan, baik pada pengujian no-choice test maupun multiple choice test mengalami kehilangan berat. Hal ini menunjukkan bahwa semua umpan yang diujikan dapat dimakan dan dikonsumsi oleh rayap. Daun kayu putih dan kertas HVS merupakan bahan - bahan yang disenangi oleh rayap. Seperti yang dinyatakan oleh Simbolon et al. (2015) bahwa rerata jumlah rayap terbanyak terdapat pada pengujian dengan menggunakan daun kayu putih. Daun kayu putih juga mengandung metil eugenol yang bersifat menarik dan memiliki aroma khas, serta dikenal sebagai atraktan alami (Noviansari et al. 2013). Kandungan sineol pada ekstrak daun kayu putih juga memberikan pengaruh yang besar terhadap kehilangan berat contoh uji. Aroma yang khas pada daun kayu putih merangsang alat sensor serangga sehingga rayap dapat tertarik untuk mendekat bahkan memakan bahan yang memiliki aroma khas tersebut.

Hasil penelitian baik pada no-choice test maupun multiple choice test menunjukkan nilai kehilangan berat tertinggi terdapat pada perlakuan A3. Hal ini diduga karena kardus lebih disenangi rayap dibandingkan dengan kertas HVS dan campuran kertas HVS + kardus, pernyataan ini sejalan dengan hasil penelitian Permana dan Husni (2017), bahwa kehilangan berat pada sampel kertas kardus lebih tinggi dibandingkan dengan sampel kertas HVS dan kardus + HVS. Kandungan selulosa yang terdapat dalam limbah kertas juga membuat rayap semakin tertarik untuk memakan umpan. Hal ini 
dipertegas dengan pernyataan Muin et al. (2014) pada penelitiannya yang memperlihatkan bahwa campuran kayu pinus terdegradasi dengan limbah kertas HVS dan atau dengan limbah karton dan kertas koran dapat diformulasikan menjadi umpan yang bersifat penarik terhadap rayap. Hal ini dipertegas dengan pernyataan Yanez et al. (2004), yang menjelaskan bahwa kardus memiliki kandungan selulosa $75 \%$ dari berat keringnya. Nilai kehilangan berat sampel terendah terdapat pada contoh uji A2. Hal ini diduga karena adanya pengaruh tinta pada kertas HVS yang mempengaruhi aktivitas makan rayap. Hal ini sejalan dengan penelitian Permana dan Husni (2017), yang menunjukkan bahwa pada contoh uji dengan bahan limbah kertas HVS merupakan contoh uji dengan nilai kehilangan berat terendah dibandingkan dengan contoh uji dari bahan lain. Dalam penelitian ini terdapat beberapa komponen penyebab kehilangan berat umpan yakni limbah kertas HVS dan kardus sebagai selulosa yang sangat digemari oleh rayap, dan daun kayu putih yang mempunyai aroma yang khas sehingga dapat menarik rayap. Komponen - komponen yang dicampurkan dalam umpan rayap tersebut menjadi pemicu utama rayap untuk memakan umpan yang diberikan, kemudian menyebabkan kehilangan berat pada umpan.

Hasil pengujian, baik metode nochoice test maupun multiple choice test menunjukkan hasil yang sama, yaitu perlakuan A3 merupakan perlakuan dengan kehilangan berat tertinggi, dan perlakuan A2 merupakan perlakuan dengan nilai kehilangan berat terendah. Hal ini menunjukkan rayap lebih menyukai contoh uji A3, baik dengan metode pengumpanan secara paksa (nochoice test) maupun dengan pilihan (multiple choice test). Tetapi, kehilangan berat setiap contoh uji pada multiple choice test mengalami penurunan dari nilai kehilangan berat no-choice test. Hal ini diduga karena pada multiple choice test, seluruh contoh uji dikondisikan dalam satu tempat sehingga rayap dapat dengan bebas memilih makanannya, sedangkan pada no-choice test rayap dipaksa memakan satu contoh uji yang ada dalam cawan pengujian.

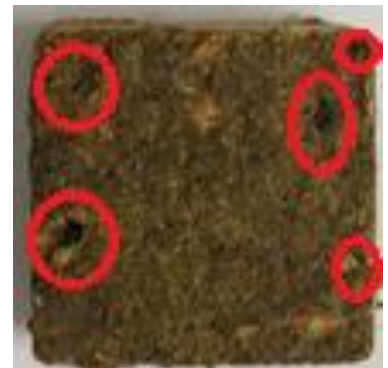

A1

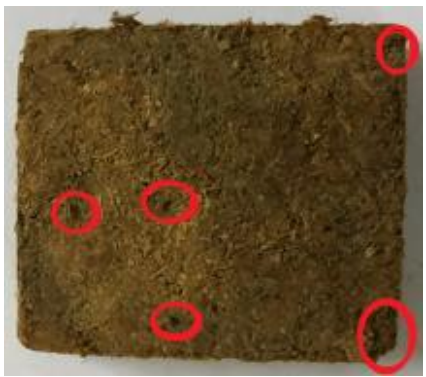

A2

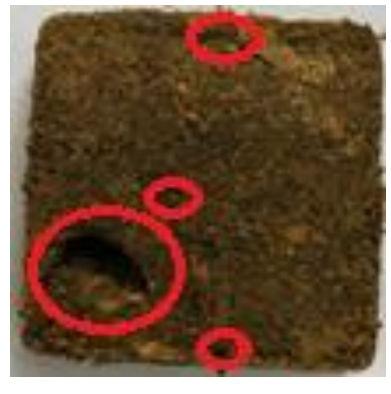

A3

Gambar 3. Bentuk Kerusakan Contoh Uji Setelah Pengujian (Form Damage of sample test after testing)

Keterangan : Bagian yang diberi tanda lingkaran pada gambar menunjukkan bagian umpan yang dimakan rayap. 


\section{Mortalitas}

Persentase mortalitas rayap yang diperoleh pada pengujian berkisar antara $86,67 \%$ hingga mencapai $100 \%$.
Rerata persentase mortalitas rayap contoh uji hasil penelitian ini disajikan pada Gambar 4.

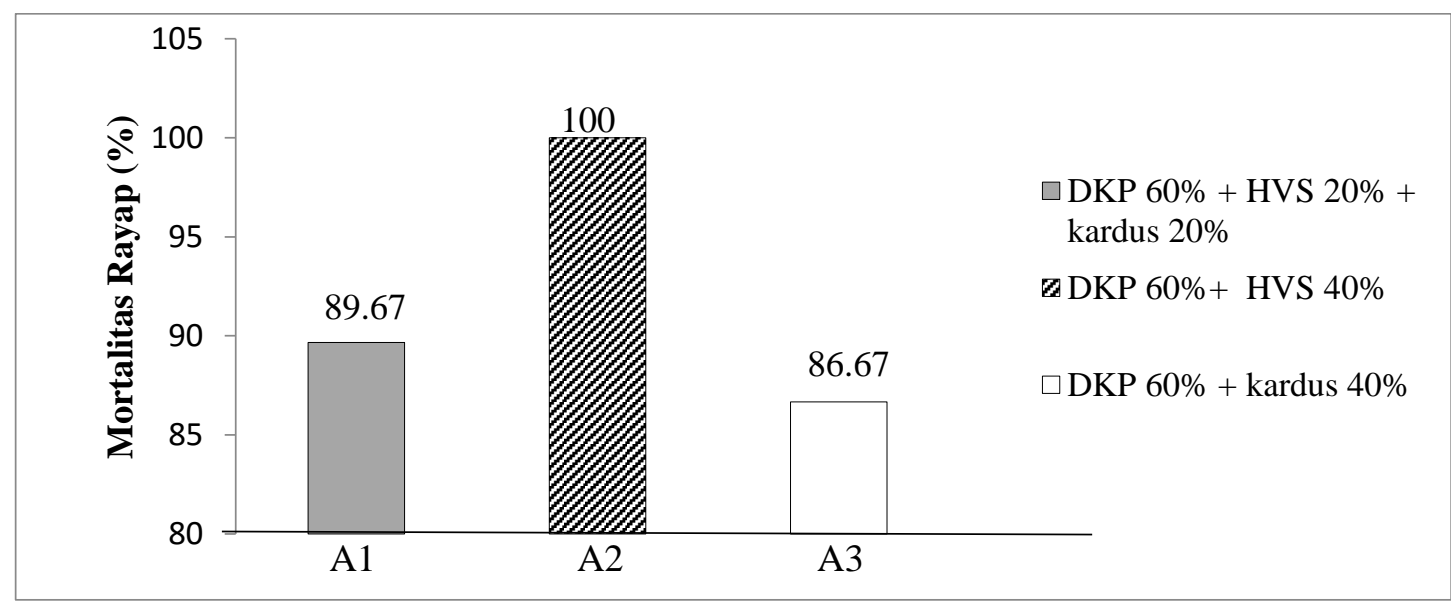

Gambar 4. Mortalitas Rayap Tanah C. curvignathus (Subterranean Termite C. curvignathus)

Efikasi campuran daun kayu putih dan limbah kertas dapat ditentukan dengan melihat banyaknya rayap yang memakan umpan. Hal ini berkaitan dengan manfaat daun kayu putih sebagai atraktan, yaitu penarik serangga. Daun kayu putih juga dikenal mengandung eugenol dan metil eugenol. Kandungan metil eugenol dalam daun kayu putih telah dikenal sebagai atraktan alami yang dapat digunakan untuk menarik rayap. Hal ini sejalan dengan hasil penelitian Simbolon et al. (2015), yang menyatakan bahwa dari lima ekstrak daun yang digunakan dalam penelitian, rerata jumlah rayap terbanyak terdapat pada pengujian dengan menggunakan ekstrak daun kayu putih. Kandungan eugenol pada daun kayu putih yang bersifat slow action, diduga menyebabkan tingginya mortalitas rayap tanah pada pengujuan. Menurut Indrayani et al. (2016), senyawa eugenol dari ekstrak daun kayu putih dan ekstrak daun cengkeh berpotensi sebagai pengendali rayap karena dapat menjadi racun atau penarik bagi rayap, tergantung dari konsentrasi dan jenis tanamannya. Selain daun kayu putih, jenis limbah kertas yang digunakan juga mempengaruhi persentase jumlah rayap mati selama proses pengujian. Kertas HVS yang digunakan dalam penelitian merupakan limbah kertas HVS yang sudah berupa limbah atau kertas HVS yang sudah digunakan dan mengandung tinta. Perlakuan A2, menunjukkan efikasi yang lebih tinggi dalam meningkatkan mortalitas rayap dibandingkan dengan perlakuan lain. Hal ini berbanding terbalik dengan hasil kehilangan berat sampel uji yang menunjukkan nilai kehilangan berat tertinggi yaitu pada contoh uji A3. Kaidah dalam metode pengumpanan, kehilangan berat selalu berbanding lurus dengan mortalitas rayap, seperti halnya pada penelitian Permana dan Husni (2017), dimana kehilangan berat dan mortalitas 
tertinggi terdapat pada komposisi sampel yang sama kayu pinus terdegradasi + limbah kertas HVS + limbah kertas kardus + ekstrak daun kayu putih 0,01\%. Namun pada penelitian ini, nilai kehilangan berat umpan berbanding terbalik dengan nilai mortalitas rayap. Hal ini diduga karena contoh uji A2 banyak ditumbuhi jamur, sehingga rayap tidak suka dengan contoh uji yang diberikan dan mengakibatkan rayap mengalami kematian.

Tingginya mortalitas pada contoh uji A2 juga diduga karena adanya kandungan tinta yang terdapat pada limbah kertas HVS, karena pada penelitian ini, limbah kertas HVS yang digunakan sebagai bahan pembuatan umpan tidak melalui proses perendaman selama 24 jam yang menyebabkan kandungan tinta dalam kertas HVS luntur, seperti yang dilakukan Permana dan Husni (2017) pada penelitiannya.

\section{KESIMPULAN}

1. Campuran daun kayu putih, limbah kertas HVS dan limbah kardus pada pengujian No Choice Test dan Multiple Choice Test ampuh digunakan sebagai umpan pada rayap tanah (C. curvignathus)

2. Daun kayu putih, limbah kertas kardus pada pengujian No-Choice Test dan Multiple Choice Test pada komposisi campuran 60\% : 40\% merupakan komposisi terbaik sebagai umpan pada rayap tanah $C$. curvignahus.

\section{SARAN}

1. Berdasarkan prinsip pengumpanan, campuran daun kayu putih 60\% : kardus $40 \%$ adalah komposisi terbaik sebagai umpan terhadap rayap tanah, sehingga dapat dimanfaatkan untuk pengendalian rayap.

2. Perlu dilakukan penelitian skala lapangan terhadap umpan yang dihasilkan dari penelitian ini.

\section{DAFTAR PUSTAKA}

Huang QY, Lei CL, Xue D. 2006. Field evaluationof a fipronil bait against subterranean termite

Odontotermes formosanus (Isoptera: Termitidae).Journal of Economic

Entomology. 99 : Laboratorium Jurnal Online Agroteknologi. 3(1) : $103-111$

Indrayani Y, Muin M, Adilla C, Yoshimura T. 2016. Crude extracts of two different leaf plant species and their responses against subterranean Termite Coptotermes formosanus Shiraki. Nusantara Bioscience 8 (2) : $226-231$

Muin M, Arif A, Nuraeni S. 2014. Pengembangan Sistem Kontrol Rayap untuk Produksi Biogenik dan Perbaikan Produktivitas Lahan Hutan Pendidikan UniversitasHasanuddin.Makassar.htt p;//repository.unhas.ac.id/bitstream/ handle/12345789/12728/ABS.musri zal\%20muin.docx?sequence $=1$.

Diakses Februari 2018.

Nandika D, Rismayadi Y, Diba F. 2003. Rayap Biologi dan Pengendaliannya, Ed. 1, Muhammadiyah University Press. Surakarta

Noviansari R, Sudarmin, Siadi K. 2013. Transformasi Metil Eugenol Menjadi 3 - (3,4 dimetoksi fenil) - 1 - Propanol dan Uji Aktivitasnya Sebagai Antibakteri. Semarang. Indonesian Journal of Chemical Science. 2 (2). : 114 - 118

Ohmura W, S Doi, M Aoyama, S Ohara. 2000. Antifeedant Activity of 
Flavonoids and Related

Compounds Against The

Subterranean Termite Coptotermes formosanus Shiraki. J. Wood Sci 46 :149-153.

Permana RD, Husni H. 2017. Efektivitas Bioatraktan dari Bahan Alami terhadap Rayap Tanah (Coptotermes curvignathus Holmgren). Jurnal Hutan Lestari 5 (3) : 629 -688.

Septiana T, Husni H. 2017. Efektifitas Campuran Daun Kayu Putih (Malaleuca leucadendra) dan Limbah Kertas HVS Sebagai Bioatraktan pada Rayap Tanah (Coptotermes sp). Jurnal Hutan Lestari 5 (4) : 1047 - 1057

Simbolon RI, Indrayani Y, Husni H. 2015. Efektivitas Bioatraktan dari Lima Jenis Tanaman Terhadap Rayap Tanah (Coptotermes sp). Jurnal Hutan Lestari 4(1) : 40 - 46.

Tarumingkeng RC. 2001. Biologi dan Perilaku Rayap (Biology and Ethology of Termites). Institut Pertanian Bogor. Bogor

Yanez R, Alonso J L, Parajo J C. 2004. Production of Hemicellulosic Sugars and Glucose from Residual Corrugated Cardboard. Process Biochemistry 39 (11) :1543 - 1551

Zulyusri, Desyanti, Mardia U. 2013. Keefektifan Daun Sangitan (Sambucus javanica Reinw) Sebagai Insektisida Nabati dalam Pengendalian Rayap Tanah (Coptotermes sp). Prosiding Semirata FMIPA Universitas Lampung. : $521-528$ 